\title{
Urgences
}

\section{L'étésie de ROSE...}

\section{Jocelyne Felx}

Numéro 15, octobre 1986

Épigraphiques

URI : https://id.erudit.org/iderudit/025299ar

DOI : https://doi.org/10.7202/025299ar

Aller au sommaire du numéro

Éditeur(s)

Urgences

ISSN

0226-9554 (imprimé)

1927-3924 (numérique)

Découvrir la revue

Citer ce document

Felx, J. (1986). L'étésie de ROSE... Urgences, (15), 32-32.

https://doi.org/10.7202/025299ar

Ce document est protégé par la loi sur le droit d'auteur. L’utilisation des services d'Érudit (y compris la reproduction) est assujettie à sa politique d'utilisation que vous pouvez consulter en ligne.

https://apropos.erudit.org/fr/usagers/politique-dutilisation/
Cet article est diffusé et préservé par Érudit.

Érudit est un consortium interuniversitaire sans but lucratif composé de l’Université de Montréal, l'Université Laval et l'Université du Québec à Montréal. Il a pour mission la promotion et la valorisation de la recherche. https://www.erudit.org/fr/ 


\section{Jocelyne Felx}

Rrose Sélavy et moi esquivons les ecchymoses des Esquimaux aux mots exquis.

Marcel Duchamp: Rrose Sélavy

L'étésie de ROSE me revient par-dessus cette rivière gavée de déchets de bois

à cause un peu du jour qui tremble sur ses genoux, étanchant les poitrines dans l'angle ocre du piano de noyer poli apaisant le matin gris des yeux.

ELLE JOUAIT EN GANTS ROSES ET

DOLCE UN CERTAIN CRI MAJEUR

DE SOL.

Me revient aussi le chapeau ivre de ROSE dans l'ombre de midi ses pastels un peu swing et la pROSE des oiseaux de clameur en clameur, au fond du jardin, la langue et le temps estivant entre l'iris et la voix, tissaient des parties de campagne entre les différents espaces, épanouissaient les saisons dans la ville.

Cette période de dissipation ne fut jamais vaine: ROSE PLAQUAIT DES AÉROPLANES DE MOUSSELINE AUX IMPROMPTUS DE CHOPIN. 